\title{
Evaluating Emissions Data: Testing Methods Matter
}

As public interest in air quality grows, so do announcements of groundbreaking emissions test data from new vehicle technologies. Although these results often look promising, it's important to consider the procedures used to reach the conclusions.

Before their products are released to market, original equipment manufacturers (OEMs) test them using procedures and equipment specified and approved by the U.S. Environmental Protection Agency (EPA). However, these testing standards are only mandatory when it's time for products to become certified for market. In the product development stages, OEMs and researchers often test products and new technologies using other procedures and equipment. When these results are released publicly, they can be confusing and difficult to evaluate.

Knowing the different types of testing procedures is helpful when interpreting emerging emissions data. This document outlines the most common vehicle and engine testing procedures and explains which ones are accepted by EPA and other regulatory agencies to certify products and shape policy. It also offers information on the different types of emissions and background on current air quality policy.

\section{Emissions Basics}

According to EPA, the vehicles we drive for work and play are responsible for emitting nearly half the air pollution in the United States*. Considered "mobile sources" of pollution, conventional petroleum-powered vehicles contaminate the air with evaporative and combustion emissions.

Evaporative emissions are hydrocarbon (HC) vapors that escape from a fuel tank or permeate through hoses and connections. Evaporative emissions are regulated by EPA because they contribute to the formation of ground-level ozone, a key component in smog.

Combustion emissions are released through vehicle tailpipes when fuel is burned in an engine. HC, carbon monoxide $(\mathrm{CO})$, oxides of nitrogen $\left(\mathrm{NO}_{\mathrm{x}}\right)$, and particulate matter (PM) are the most common types of combustion emissions and are regulated by EPA because they impact ground-level ozone and human health.
- HC pollution results when unburned or partially burned fuel is emitted from the engine as exhaust and when fuel evaporates directly into the atmosphere. A component of most fuels, HCs also react with $\mathrm{NO}_{\mathrm{X}}$ in the presence of sunlight to form ozone.

- CO forms when the carbon in fuel isn't burned completely due to a lack of oxygen. That's why high levels of CO generally occur at high altitude where less oxygen is present to help with combustion.

- $\mathrm{NO}_{\mathrm{x}}$ gases are formed when oxygen and nitrogen in the air react with each other during combustion. The most abundant pollutant, nitric oxide (NO) oxidizes in the atmosphere to form nitrogen dioxide $\left(\mathrm{NO}_{2}\right)$, which can oxidize to form ozone or air particles known as $\mathrm{PM}_{2.5}$. The formation of $\mathrm{NO}_{\mathrm{X}}$ is most common when there are high temperatures and excess oxygen. Because $\mathrm{NO}_{\mathrm{x}}$ is most abundant when combustion temperatures are high, and $\mathrm{HC}$ and $\mathrm{CO}$ are most abundant when temperatures are low, there is a trade-off among these emissions. Engines are calibrated to make the best of this trade-off.

- Particulate matter (PM) is a pollutant emitted primarily by diesel-fueled vehicles and poorly-maintained gasoline-powered vehicles. PM is made up of small particles that contain a variety of chemical components. Larger particles are visible as smoke or dust and settle out relatively rapidly. Smaller particles, such as $\mathrm{PM}_{2.5}$ can be suspended in the air for long periods of time and inhaled into the lungs.

Another significant tailpipe emission is carbon dioxide $\left(\mathrm{CO}_{2}\right) \cdot \mathrm{CO}_{2}$ is considered a greenhouse gas because it absorbs and re-emits infrared radiation that heats the earth's surface-a process known as the "greenhouse effect." $\mathrm{CO}_{2}$ is not currently regulated by EPA, but many states are examining their legislative options.

EPA and state governments are also beginning to study the effects of a variety of other vehicle emissions known as "air toxics," which are suspected of causing cancer or other health problems. These emissions include benzene and formaldehyde. 


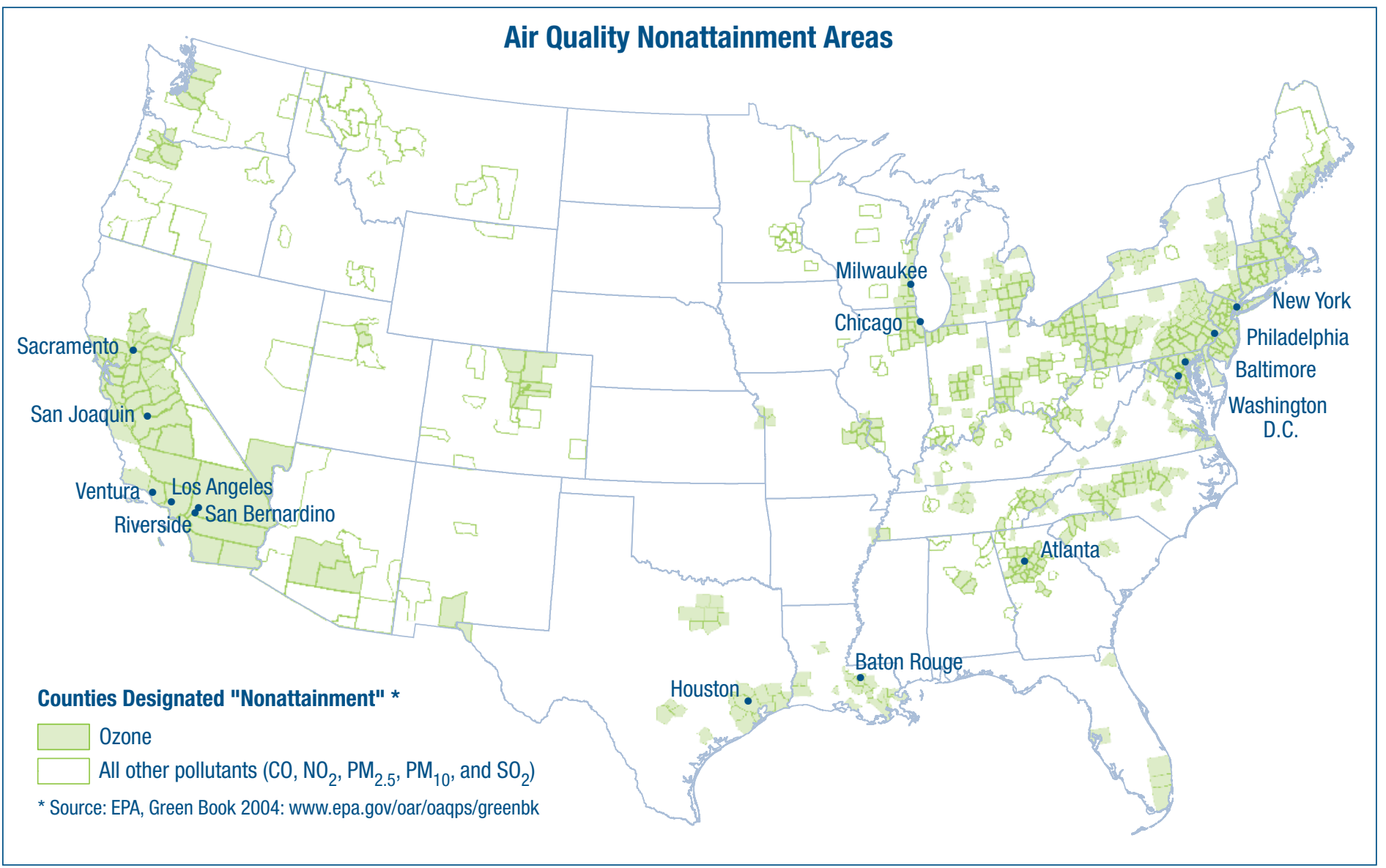

Only four states, Vermont, Oklahoma, and North and South Dakota, are in attainment for ozone and all other air pollutants.

\section{Regulating Air Quality}

Beginning with the Clean Air Act of 1970, EPA developed a regulatory program for OEMs to manage vehicle emissions-both evaporative and combustion. Early programs focused on $\mathrm{CO}$ and $\mathrm{HC}$ emissions but, because of a better understanding of how pollution affects air quality, regulatory programs have expanded to cover $\mathrm{NO}_{\mathrm{x}}$ and PM emissions.

EPA monitors air quality across the country. Areas with ozone pollution numbers exceeding EPA's established limits are considered in "nonattainment." These areas must develop special strategies, called state implementation plans (SIPs), identifying initiatives that will improve local air quality. The plans consist of programs that address emissions from both mobile and stationary (e.g., building or factory) sources. Common mobile emission-reduction programs include vehicle inspection, clean fuel, and maintenance programs.

Each activity a state chooses to reduce local air pollution is evaluated in an air quality model developed by EPA using emissions data from tests simulating air quality implications in real-world scenarios. Using these models, all the activities that contribute to air quality can be com- bined and evaluated based on their contributions to local air pollution. Currently, more than 25 states have areas in nonattainment and have to maintain state or metropolitan area implementation plans.

\section{Testing Methods}

There are two types of emission testing: certification and non-certification. To verify that vehicles and engines meet emission standards outlined in the Clean Air Act and its amendments, vehicle and engine manufacturers must certify all their products with EPA prior to offering them for sale. OEMs complete testing according to procedures set forth by EPA for various configurations of vehicles that are sold each model year. This testing is typically done using chassis and engine dynamometers and analyzers.

\section{Certification Testing}

Light-duty vehicle OEMs use a chassis dynamometer and analyzer to evaluate emissions for certification. This testing device consists of a single roller that spins against the wheels of the vehicle, allowing an operator to take the vehicle through a prescribed drive cycle of speeds, accelerations and decelerations, and starting and stopping. During the test, the vehicle's emissions and fuel use are measured, collected, and analyzed. 
Summary of Emissions Measurement Technologies

\begin{tabular}{l|c|c|c|c|c|c|c|c} 
& $\begin{array}{c}\text { Measures } \\
\mathrm{HC}\end{array}$ & $\begin{array}{c}\text { Measures } \\
\mathrm{CO}\end{array}$ & $\begin{array}{c}\text { Measures } \\
\mathrm{NO} \mathrm{x}^{\text {Equipment }}\end{array}$ & $\begin{array}{c}\text { Measures } \\
\mathrm{PM}\end{array}$ & $\begin{array}{c}\text { Acceptable } \\
\text { for Emission } \\
\text { Certification }\end{array}$ & $\begin{array}{c}\text { Results Repeat- } \\
\text { able between } \\
\text { Experiments }\end{array}$ & $\begin{array}{c}\text { Measures Real- } \\
\text { World Driving } \\
\text { Conditions }\end{array}$ & $\begin{array}{c}\text { Incorporates } \\
\text { Engine/Vehicle } \\
\text { Feedback }\end{array}$ \\
$\begin{array}{l}\text { Chassis } \\
\text { Dynamometer } \\
\text { and Analyzer }\end{array}$ & $\mathrm{x}$ & $\mathrm{x}$ & $\mathrm{x}$ & $\mathrm{x}$ & $\mathrm{x}$ & $\mathrm{x}$ & $\mathrm{x}$ \\
\hline $\begin{array}{l}\text { Engine } \\
\text { Dynamometer } \\
\text { and Analyzer }\end{array}$ & $\mathrm{x}$ & $\mathrm{x}$ & $\mathrm{x}$ & $\mathrm{x}$ & $\mathrm{x}$ & $\mathrm{x}$ & $\mathrm{x}$ \\
\hline $\begin{array}{l}\text { Remote } \\
\text { Sensing }\end{array}$ & $\mathrm{x}$ & $\mathrm{x}$ & $\mathrm{x}$ & & & $\mathrm{x}$ & $\mathrm{x}$ & \\
\hline $\begin{array}{l}\text { Portable } \\
\text { Emissions } \\
\text { Measurement }\end{array}$ & $\mathrm{x}$ & $\mathrm{x}$ & $\mathrm{x}$ & & & & $\mathrm{x}$ & $\mathrm{x}$ \\
\hline
\end{tabular}

For heavy-duty vehicles, current regulations require certification of the engine, not the whole vehicle, because of the wide variety of types of vehicles and drive cycles. Engine OEMs test heavy-duty engine emissions using an engine dynamometer and analyzer that controls the operation of an engine installed on a test stand in a laboratory setting. Emissions are measured and analyzed at various horsepower and torque settings.

Because chassis and engine dynamometers produce consistent, repeatable results, they are required by EPA and other environmental agencies in certification testing. When reviewing emerging emissions test results, be sure to find out if they were obtained using this government-approved equipment.

\section{Non-certification Testing}

Chassis and engine dynamometers and analyzers can also be used for non-certification testing in research and development. Many laboratories and companies use dynamometers for the same reason OEMs do: They generate well-understood results that compare with data gathered among most entities. However, dynamometers lack the flexibility offered by remote sensing and portable emissions measurement systems, two common non-certification methods. Although these non-certification testing methods are not accepted by EPA, they are useful for spotting trends or issues in emerging technologies.

Remote sensing measures emissions by shooting a light beam through a vehicle's exhaust stream as the vehicle passes the testing equipment. Remote sensing is currently being used to screen vehicles in local emission testing programs. In some locations, vehicles with "clean" emissions readings are waived from their scheduled emissions test. In addition, state governments are starting to use this testing

\section{SIPs and Modeling Programs}

The Clean Air Act requires states in nonattainment to write SIPs, which outline strategies to attain and maintain national ambient air quality standards. Measures listed in SIPs include initiatives like minimizing emissions through the purchase of low or zero-emission cars or using clean-burning fuels in alternative fuel vehicles (AFVs).

Once a SIP is in place, fleets in nonattainment areas generally can't make vehicle changes that increase emissions without identifying and implementing activities, such as carpooling or high occupancy vehicle lanes, that offset increases. To help states determine the impacts of vehicle-related emissions, EPA developed MOBILE (www.epa.gov/otaq/mobile.htm), a complex modeling program that uses approved research findings as a basis for valuing the emissions impacts of vehicle programs. The AirCRED (www.transportation.anl.gov/ software/AirCred/index.html) model is a subsection of MOBILE that estimates air quality impacts of AFVs in fleets. It was developed by Argonne National Laboratory for Clean Cities.

Fleets, coalitions, and state agencies can use these models to help them determine projects or vehicle technologies that would best address air quality concerns in their area.

technology to spot high-emitting vehicles and flag them for further analysis through official state vehicle inspection.

Although remote sensing is an effective testing method, it is difficult to verify results because exact vehicle operating conditions can't easily be recreated from test to test. Plus, remote sensing is limited to use on one-lane highways and on-ramps where cars pass one at a time. Currently, remote 


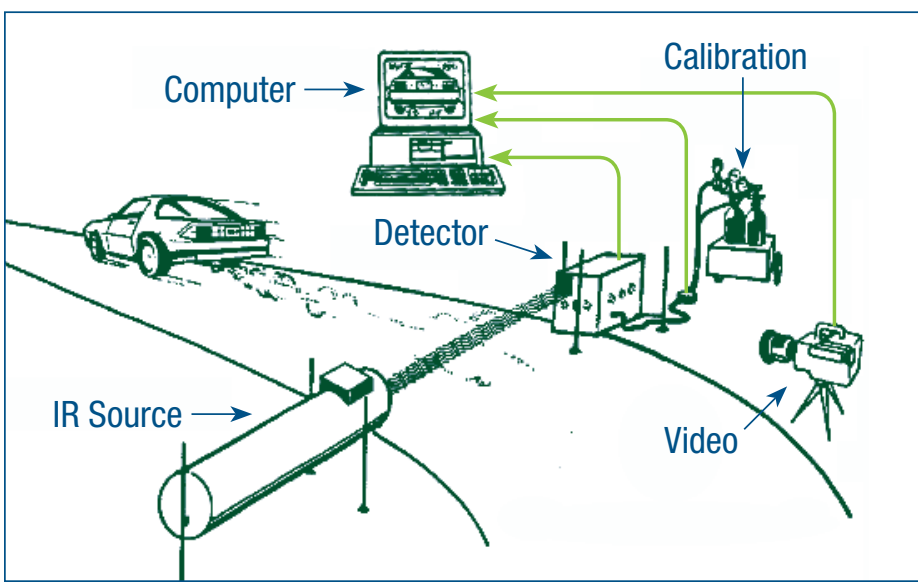

Remote sensing equipment measures emissions by shooting a light beam through a vehicle's exhaust stream as the vehicle passes it.

sensing equipment can test only $\mathrm{CO}, \mathrm{HC}$, and $\mathrm{NO}$ emissions. However, emerging technologies may soon be able to measure PM emissions, as well.

Portable emissions measurement systems (PEMS) are small units that are attached to or set inside a vehicle. PEMS collect real-world driving data using a probe that is inserted into the tailpipe. Used by vehicle and engine manufacturers during product development, they collect data that correlate emissions with vehicle operating conditions such as speed, acceleration and deceleration, and power and torque. Like remote sensing equipment, PEMS measure $\mathrm{HC}, \mathrm{CO}$, and $\mathrm{NO}_{\mathrm{x}}$, but not PM.

Because PEMS involve one entire system per vehicle, they can be costly to use on a fleet basis. Plus, they must be completely removed and reinstalled when moved from vehicle to vehicle, so they don't offer fully repeatable results between installations. Therefore, PEMs are best suited for evaluating emerging technologies and prototype vehicles or gathering a wide range of operating parameters in one vehicle.

Even though remote sensing equipment and PEMS play important roles in various types of emissions testing, it's important to note testing results that were obtained using this equipment. Because these testing methods are not standardized, results collected from them should be considered preliminary.

Sponsored by the U.S. Department of Energy

Energy Efficiency and Renewable Energy

FreedomCAR and Vehicle Technologies Program

For more information contact: EERE Information Center

1-877-EERE-INF (1-877-337-3463)

www.eere.energy.gov

A Strong Energy Portfolio for a Strong America

Energy efficiency and clean, renewable energy will mean a stronger economy, a cleaner environment, and greater energy independence for America. Working with a wide array of state, community, industry, and university partners, the U.S. Department of Energy's Office of Energy Efficiency and Renewable Energy invests in a diverse portfolio of energy technologies.

DOE/GO-102006-2301 • April 2006

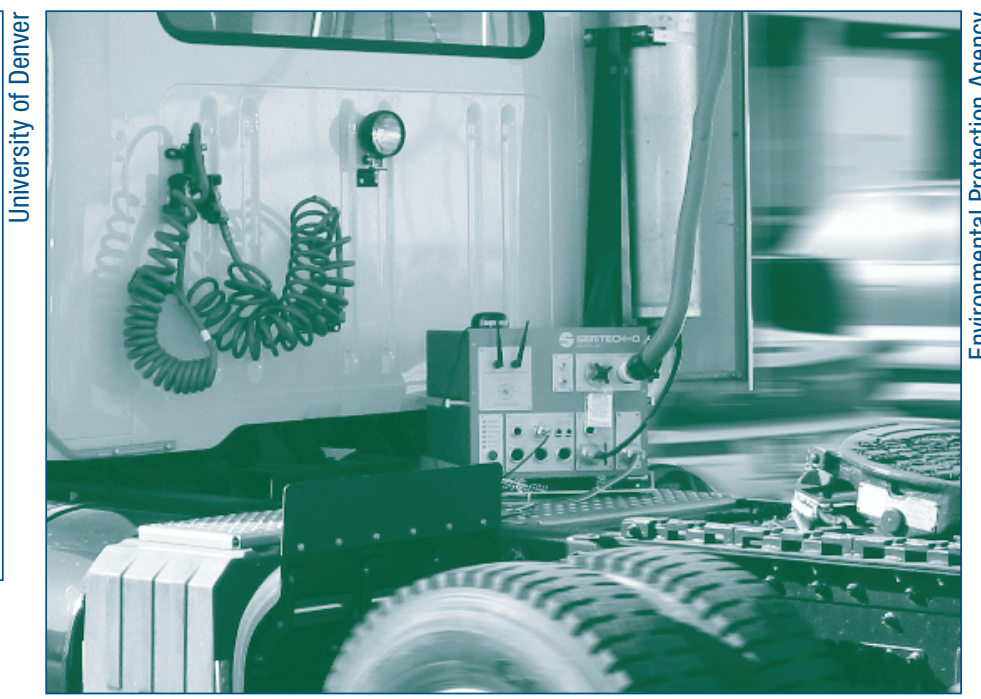

Portable emissions measurement systems collect real-world driving data using a probe that is inserted into the tailpipe.

\section{For More Information}

- EPA Mobile Source Emissions Web site: www.epa.gov/oms/index.htm

- Inventory of U.S. Greenhouse Gas Emissions And Sinks 1990-2003: http://yosemite.epa.gov/oar/globalwarming.nsf/ content/ResourceCenterPublicationsGHGEmissionsUSEmis sionsInventory2005.html

- Federal and California Exhaust and Evaporative Emission Standards for Light-duty Vehicles and Light-duty Trucks: www.epa.gov/otaq/cert/veh-cert/b00001.pdf

- Emission Standards Reference Guide for Heavy-duty and Nonroad Engines: www.epa.gov/oms/cert/hd-cert/stds-eng.pdf

\section{Bottom Line}

When evaluating emerging emissions results, it's important to remember that not all data are equivalent. From OEMs to research facilities, every organization uses different equipment and standards to test their technologies. Therefore, results should be considered with care.
Prepared by the National Renewable Energy Laboratory (NREL) NREL is a U.S. Department of Energy National Laboratory Operated by Midwest Research Institute $\bullet$ Battelle

Neither the United States government nor any agency thereof, nor any of their employees, makes any warranty, express or implied, or assumes any legal liability or responsibility for the accuracy, completeness, or usefulness of any information, apparatus, product, or process disclosed, or represents that its use would not infringe privately owned rights. Reference herein to any specific commercial product, process, or service by trade name, trademark, manufacturer, or otherwise does not necessarily constitute or imply its endorsement, recommendation, or favoring by the United States government or any agency thereof. The views and opinions of authors expressed herein do not necessarily state or reflect those of the United States government or any agency thereof.

Printed with a renewable-source ink on paper containing at least $50 \%$ wastepaper, including $10 \%$ postconsumer waste. 